\title{
Evaluating Learners' Satisfaction with a Distance Online CLIL Lesson During the Pandemic
}

新冠肺炎疫情期間評量學習者對線上「學科內容與語言學習結合教學 法」遠距課程之滿意度研究

\section{Wen-hsien Yang ${ }^{1} \cdot$ Li-zu Yang $^{2}$}

Received: 28 November 2020 / Revised: 19 May 2021 / Accepted: 31 May 2021 /

Published online: 14 June 2021

(C) National Taiwan Normal University 2021

\begin{abstract}
Due to the outbreak of the pandemic in 2020, numerous schools have had to shut down. Many universities are still continuing the distance learning model in 2021, including Taiwan. Although the benefits and challenges of distance learning have been extensively studied, there has been less research on whether the ICLHE (Integrated Content and Language in Higher Education) approach, which greatly relies on face-to-face interaction and collaborations with peers, can work well in a distance learning model. Thus, 4 weeks of synchronous ICLHE teaching was conducted as a trial in a Taiwan university. The students were asked to complete a weekly online survey to evaluate their learning, the practitioner's teaching, and the platform. Results revealed that ICLHE may not work well in a distance learning situation due to decreasing motivation, greater distraction, lack of actual interaction, peer pressure, teacher monitoring, and practitioner's fatigue. The study cautions against implementing ICLHE according to a distance learning model.

\section{摘要}

鑑於2020年新冠肺炎疫情的爆發，許多學校不得不關閉校園。而包括台灣在內，許多大學仍 在2021年繼續採用遠距學習模式達成「停課不停學」。儘管已經有廣泛的研究提出了遠距 學習的好處和挑戰, 但是關於ICLHE(高等教育中的內容和語言整合學習)教學法能否有效地 進行遠距授課的研究卻很少, 肇因該方法在很大程度上依賴於與同儕間實際面對面的互動和 合作學習。因此, 本研究即利用為期四週的時間進行一門同步遠距ICLHE教學課程以驗證學 習效能。每週課後, 學生被要求填寫線上問卷調查, 以評量他們的學習效果、教學者的教學 效能和課程操作平台。研究結果顯示, 由於學習動機下降、注意力分散、缺乏實際互 動、同儕壓力、老師監控和教學疲勞等因素, ICLHE在遠距學習環境中可能無法很好地發 揮作用。本研究的結論是遠距學習模式可能無法適用於ICLHE教學法。
\end{abstract}

Keywords CLIL · ICLHE · University lockdown · Distance learning · Teaching effectiveness $\cdot$ Learner's satisfaction 
關鍵詞 學科內容與語言學習結合教學法·高等教育中的內容與語言整合學習·大學關閉·遠距 教學·教學效能·學習者滿意度

\section{Introduction}

The year 2020 can be marked as a very different and difficult time in human history. Due to the outbreak of the COVID-19 pandemic, nearly all travel, business activities, social events, and schooling were temporarily suspended or closed. Thus, working and learning online during the pandemic seemed to be the only option to keep the world going. Teachers across all educational levels were suddenly required to deliver their teaching via a distance or online model to ensure that learning could continue, without having much time to prepare or re-design courses. Large-scale conducting of distance or online learning is now being seen across the world, and some world-leading universities such as the Cambridge University [92], Oxford University [93], Massachusetts Institute of Technology [59], and Harvard University [38] have announced that remote teaching and learning will continue until mid-2021. The distance learning model is currently replacing rather than assisting ordinary classroom instruction in education scenarios.

Using technology to support students' learning at tertiary level is not unusual [40]; the notion of computer-assisted instruction in fact appeared as early as the 1950s [90]. Distance education assisted by technology is a multidimensional concept and a pedagogy very different from that in ordinary classrooms. Distance learning has a distinct teaching philosophy of open-access learning and organisational forms [61]. In other words, the educational approaches derived from actual classrooms may be able to fit distance or online education modes if courses are properly re-designed. However, during the pandemic, teachers and students are being requested to stay online for distance instruction despite the fact that teaching approaches, learning methods, course materials, and mindsets have not been adapted. A quick response to the policy is mainly a direct transplantation of what is normally done in classrooms adopting a remote model. Thus, both learners and teachers are likely to feel isolated, helpless, or anxious, with little time or assistance to quickly adapt to an instructional mode which they have seldom or never experienced before.

Teaching performance, course delivery methods, and learners' achievements in classrooms and remote education around the world have been greatly affected by the pandemic (e.g. [1, 80, 82, 88, 94]). Yet, relatively little attention has been paid to the impact of the pandemic on CLIL (Content and Language Integrated Learning), one of the popular and widespread educational approaches in bilingual programmes across European contexts [20] and in some Asian countries [50]. In addition to accommodating dual focuses of both content and language learning, CLIL education also emphasises how learners can participate socially to achieve interpersonal functions in real classrooms [51], and thus it is assumed that it would also be considerably influenced if it had to be conducted via a distance model. Hence, to bridge this gap, this article reports an experiment of conducting a remote ICLHE course in a Taiwan university to gauge the possible changes to teaching practices and learning efficacy and to depict the implementation challenges posed by school lockdown. 


\section{Previous Studies Reviewed}

\section{The CLIL/ICLHE Approach and Its Recent Developments}

CLIL is an educational approach in which a target language is used as a tool in the learning of a non-language discipline, and thus language and the subject share a common goal [12]. It is, nowadays, viewed as a generic term to refer to all kinds of approaches where some proportion of language scaffolding is provided to learners in order to assist their learning of the subject matter through the second language. However, in university settings, ICLHE is considered to be a more appropriate and preferred term [86].

The effectiveness of developing learners' linguistic skills under the CLIL approach has been extensively documented across European contexts. In general, learners' receptive skills such as listening and reading and vocabulary would show satisfactory progress [17]. However, some productive skills such as writing, pronunciation, or pragmatics cannot be significantly enhanced. Compared to their non-CLIL peers, it was found that CLIL students were relatively more capable of exhibiting longer speech acts, constructing positive attitudes towards the target language, and demonstrating a higher command of the language [14, 23, 52, 83, 97]. CLIL is evidenced to help improve learners' linguistic competence in the target language despite the fact that the L2 has little social exposure in the context [47]. Moreover, other than linguistic benefits, CLIL also brings long-term advantages to students. For example, this approach can serve as a powerful drive to keep CLIL learners motivated in learning the target language as they are usually expected to communicate with their classmates in the L2 in the content course [13, 47, 54, 84, 85, 87]. Moreover, CLIL helps its learners cultivate a positive international orientation [81], intercultural citizenship [78], and an international posture [53]. CLIL also prepares its learners for their careers as it helps equip them with higher mobility, employability, and cross-cultural competence in the global job market [14, 23].

In addition to the large number of studies on linguistics development, investigations on discourse and pedagogy in the CLIL classroom prevail. It was found that more negotiation of meaning was detected in CLIL classrooms than in L1 content course classrooms, and CLIL learners showed a tendency for a collaborative form of talk [58, 66]. However, they also systematically rely on their L1 to clarify difficulties in understanding lectures [32]. Furthermore, CLIL practitioners show a reduced range of teacher language such as less humour, spontaneity, and stylistic variation and change their interpersonal patterns; for example, an informal style and interacting with familiar peers dominate the classroom, and little attention is paid to academic register and subject-cognitive functions of discourse [65, 66]. Thus, some CLIL researchers (e.g. [11]) argue that language features in academic discourse should be explicitly attended to by both teachers and learners in order to balance form and meaning and to facilitate pluriliteracies. Nikula et al. [66] and Dalton-Puffer [18] also found that group size, types, and quality of teacher question and tasks would affect students' utterances in the classroom. For instance, the teacher's use of extended types of questions led to more elaborated student utterances, while students produced the richest language in role-play activities and tended to use their L1 more frequently in pair or group work. L1 was the language of creating, while L2 (TL) was the language of presenting. However, teaching 
cultures and traditions in local contexts are crucial to classroom discourse and have to be considered when CLIL teacher education is designed [75].

CLIL pedagogy has many overlaps with what other language instruction approaches propose (see [15, 74, 75]). For example, CLIL is student-centred, which is similar to task-based, project-oriented, and cooperative learning methods. CLIL follows constructivist principles, which is also identical to inquiry-based and discovery learning methods. Besides, CLIL advocates language awareness, which does not differ from content-teaching and language-scaffolding principles. Also, the notion of language across curricula (LAC) in CLIL includes the concepts of co-teaching and the integration of work and curriculum. Furthermore, in classroom practices, empirical research shows differentiated facets. Some studies have shown that there is no actual difference between CLIL and non-CLIL pedagogical designs (e.g. [2, 16, 39]), while others claim that it seems easier to say than to do CLIL in the classroom (e.g. [4, 45, 49]). However, after a longitudinal implementation of CLIL for 15 years, an increasing number of advantages have been revealed in Spain such as purposefully designed materials, a learner-centred methodology, or varied assessment methods (e.g. [24, 44, 69]). Even in a relatively young CLIL context, Poland, CLIL practices have been confirmed to be effective in terms of helping learners acquire TL grammar based on the original content-based structured input [96]. In other contexts, CLIL has also proved to be a trigger for innovative pedagogy. For instance, in Italy CLIL was integrated into a flipped classroom design for physics education, and learners significantly outperformed their counterparts [7]. Yet, the effect size only reached $r=.0394$ ( $\mathrm{p}$-value $=.8518, \mathrm{~N}=$ $50)^{1}$ which demonstrates a rather small correlation with the mediation between the control and the experimental groups. In Japan, CLIL was combined with the PBL (problem-based learning) approach to enhance learners' motivation and attitudes towards university English classes [71].

In Chinese-speaking contexts such as China and Taiwan, CLIL or EMI is rapidly emerging as an innovative approach to respond to the urges to implement bilingual education and is also highly supported by the stakeholders [98, 99, 108]. Chinese students demonstrated slightly favourable attitudes towards courses taught in a foreign language, mainly English (EMI) at tertiary level and CLIL-type bilingual education at pre-tertiary level [43]. Although some challenges and difficulties such as insufficient national or regional funding support, unsteady policy-making, a lack of qualified CLIL teacher preparation, or learners' perceived unfairness of English native speakers' dominance in the international academia $[43,99,109]$ may hinder full-scale implementation of CLIL or EMI, the strong popularity of learning content in the target language in both modes is still expected to grow rapidly in the future [98]. These discussion and cases help predict its potentially successful adaptation to diverse contexts. However, a cyber or a distance CLIL learning situation without genuine classroom instruction has not yet been extensively explored; thus, whether similar positive results will occur is questionable.

\footnotetext{
${ }^{1}$ The effect size (r) was calculated by the authors by using the data provided in Capone et al. and private correspondence to obtain the numbers of the participants in the two groups, i.e. 25 in each and thus $\mathrm{N}=50$ in total.
} 


\section{Technology-Mediated Distance Education}

During school lockdown due to the pandemic, adopting distance or online education has become the only option to keep students learning; this was not, however, the original rationale for promoting this kind of education model. Distance learning can generally be divided into two modes, namely synchronised and asynchronised, each with its own benefits and downsides. Yet, due to the school closures and limited time for re-designing courses, most distance learning is being delivered via a synchronised model during the pandemic.

Similar to CLIL, the term 'distance education' is evolving and can be used as an umbrella term, meaning that 'some form of instruction occurs between two parties (a learner and an instructor), it is held at different times and/or places, and used varying forms of instructional materials' ([62]: 130). The core feature of distance education is its self-directed and learner-controlled learning activities whereby learners take control of learning and monitor its pace and progress without learner-to-learner interaction [30]. Differing from conventional classrooms, communication between teachers and learners in distance education occurs remotely, and is usually mediated or assisted with technology [31]. Yet, both Florini [26] and James and Gardner [41] cautioned that without proper design of electronic delivery to fit different learning styles, distance learning cannot be effective or efficient. A sound instructional design should include the following steps: assessing entry behaviour; specifying behavioural objectives, learning units, and procedures; presenting learning units and tasks; and evaluating student performance [95].

Although studies on the teaching effectiveness or learning satisfaction in technology-mediated distance education have been comprehensively recorded, these assessments are still vital as they can help plan courses and predict or evaluate the possibilities and challenges of learners receiving distance education in the future [77]. For instance, Liaw's [48] study reveals that users' perceived self-efficacy can be a useful indicator for judging learners' satisfaction with distance learning, and the effectiveness of this learning mode can be greatly affected by multimedia instruction, interactive learning activities, and platform quality.

Most of the previous studies commonly accepted the claim that no significant differences in learning outcomes were detected between online and traditional courses; however, some researchers have proposed that the effectiveness of distance learning may not be as expected [89]. Ni [64] compared students' performance under online and classroom instruction in a university course and found that the learners enrolled in the online learning model had a higher failure rate than those in the classroom group, and the students under classroom instruction reported higher successful learning experiences than the online group, owing to the reason of the online group's lower persistence; however, the effect size ( $r=.082)$ of the study seems to be below a small effect ${ }^{2}$. Similarly, Williams' [103] comparison study, showing an effect size of .50, and Cohen's recommended power of .80 evidenced that the students under face-to-face instruction significantly outperformed those in remote learning mode in the achievement test scores within the acceptable cut-off range ( $\mathrm{d}=.50$ to 1.0 ), and the same results

\footnotetext{
${ }^{2}$ The effect size (r) was calculated by the authors by using the data provided in the article [64], i.e. Chisquare $=8.16$, d.f. $=7$, p-value $=.32$, and $\mathrm{N}=148$.
} 
were reported in Brown and Liedholm's (2002) study on a graduate level virtual course. Wu's [104] review highlighted that learners' demographic background such as gender, educational level, age, experience of distance learning, delivery platform, and course type can significantly relate to the effectiveness and acceptance of distance education by learners with the effect sizes ranging between medium $(r=.38)$ and high $(r=.72)$. Learners' interaction with course content, their instructors, their classmates, and course interfaces in distance learning differ greatly from those in real classrooms [89]. As $\mathrm{Ni}$ [64] warns, online teaching may not be equally effective in different courses, and the online setting cannot be well situated in some educational programmes. CLIL is therefore an educational approach which is under-researched in terms of the learning effectiveness of distance education.

\section{CLIL Courses Conducted via the Distance Education Model}

Compared to other language teaching approaches or methods in ELT (English Language Teaching) which have been extensively incorporated with a distance or online instruction model by applying technological resources [25], studies on and application of this model with the CLIL approach have been limited, although some CLIL pre- and in-service teacher preparation courses have been designed or provided with distance or online models to enhance training efficacy and teaching competences (e.g. [21, 29, 37, $42,56,73]$ ). Designing CLIL teacher training programmes embedded with technological assistance has been evidenced to be effective in terms of engaging CLIL practitioners in developing reflective concepts and cognitive training [29].

However, studies on whether or not a distance or online CLIL course targeted at learners can lead to similar positive consequences are still lacking, in particular at tertiary level. Presently, most of the available distance or online CLIL courses were designed according to the MOOCs (Massive Open Online Courses) model and are targeted at elementary or secondary school students. In Kao's [42] exploratory action research, she firstly offered the CLIL student teachers 8 weeks of training and then had them conduct 9 weeks of online trial teaching to the elementary students. Those young learners were found to show an increment in their reading and listening skills; yet, it should be noted that Kao's delivery scenario was in an actual school where the pupils still clustered together in a classroom while watching the novice teachers teaching on the screen.

Online learning is always closely associated with self-directed learning. De Waard and Demeulenaere [22] produced a MOOC-CLIL project to guide 5th-grade learners to develop learner autonomy and concluded that there was progress in their practical language use, higher confidence in planning self-regulated learning, and enhanced social learning skills. O'Dowd (2018) suggested combining virtual exchange or telecollaboration in planning CLIL courses to motivate learners and develop intercultural collaboration initiatives, although no experiments or evaluations were carried out.

One of several investigations in higher education is Titova's [91] study which blended a MOOC course with the CLIL approach. The undergraduates reported better familiarity with the subject matter, interactive experience sharing, and development of writing skills and digital literacies. However, negative impacts also arose, such as the extra time requirement or the overloaded schedule of the online course. Other obstacles of applying ICT in CLIL courses include a lack of consideration of the learners' 
experiences, interests, and styles and a shortage of proper training on how to integrate ICT offered to practitioners [28]. Pellegrino et al. [72] designed a virtual linguistics CLIL classroom by applying a series of collaborative and communicative technologybased activities. Much interaction happened between the learners and the practitioner; the students were found to actively engage in meaningful communicative practice and content exchange and eventually developed learning autonomy and awareness. One experimental study by Marenzi and Zerr [55] evaluated two online CLIL courses which were designed using the platform LearnWeb2.0, which allowed learners to share and work collaboratively on web resources. The users generally reported a positive attitude towards the supporting, sharing, and collaboration functions. However, some grievances were aired for future implementations; for instance, reliability of the system (e.g. the connecting speed) and users' expectations in different cultures were major concerns.

When technological resources are introduced in ordinary CLIL instruction to display online or distance education features, they are not expected to completely replace the actual classroom teaching but rather to assist it. They are meant to engage the CLIL students in an active and self-directed learning mode [8]. However, during the pandemic, the distance or online education model has become the dominant mainstream education approach and is very likely to continue for a much longer period of time. Besides, as suggested by Marsh [57], future CLIL education should be given via a mixed media distance model to fit learners' characteristics, regardless of their place of residence. Thus, our study may be one of the first to anticipate the likelihood of CLIL education being conducted via the distance or online model for a rather long duration at universities. To be specific, our research questions are as follows:

(1) How has learners' satisfaction changed in a distance CLIL course over time?

(2) What are the students' perceptions of a CLIL course taught in a distance mode?

\section{Methods}

\section{Context and the Participants}

The present research was conducted in a national polytechnic university in Southern Taiwan, well-known for its 'sandwich curriculum' in hospitality and tourism disciplines, where all the students are required to complete a 1-year industrial placement in their third year of study, either in Taiwan or overseas. The 40 participants came from a single academic unit, i.e. the Department of Applied English (AE), affiliated with the International College of the University, and all of them were freshmen by mid-2020. These students had to pass the CEFR B2 level of English proficiency before graduation, although over a half of them had passed this benchmark in the first year.

The curriculum in AE generally comprises two major categories, English language skills courses and hospitality and tourism content courses. The former can be further divided into English for general purposes (EGP) and for specific purposes (ESP) courses in which a language-driven CLIL mode (or a weak CLIL version) was adopted with higher emphasis on language skills and partial accommodation of content learning 
such as in the courses of English for MICE industries (Meeting, Incentive Travel, Convention, and Exhibition) or English for intercultural competence. In contrast, nearly all of the context courses were delivered in a content-oriented CLIL mode (or a strong version) with a rather high content and language exposure [3]. ICLHE and EMI (English as a Medium of Instruction) are two common teaching methods used in this mode. Examples of content-oriented CLIL courses include Introduction to Hospitality, Introduction to Food and Beverages, Introduction to MICE Industry, or Theme-based Professional Seminars. So far, the ICLHE approach has been used in AE for 3 years and has proved effective and been welcomed by the AE learners in terms of enhancing their language proficiency, content knowledge, critical thinking skills, and intercultural competence [106]. All the courses adopting the ICLHE approach in AE have face-toface teaching in actual classrooms. Since the pandemic is well controlled with fewer than 650 cases reported (as of November 2020) by the Taiwan government, no university was ordered to be on lockdown, and thus school education has continued as normal. Thus, none of the current participants had attended any distance ICLHE courses before this research.

\section{The ICLHE Course as an Experiment}

Although there was no university lockdown in Taiwan in 2020 due to the outbreak of the virus, schools and teachers were still strongly encouraged to practise conducting online or distancing teaching models in the event that they would be needed in the future ${ }^{3}$. Thus, we decided to use the ICLHE course 'Introduction to Hospitality' for trial purposes in the spring term of 2020. Teaching materials for this course were tailor produced on the basis of delivering subject matter, training communication skills, developing cognitive thinking, and raising intercultural knowledge. Thus, each lesson included content reading, communicative activities, and language learning. In May and June of 2020, 4 consecutive weeks of lessons were conducted with 2-h distance teaching mode and 1-h face-to-face teaching mode each week. Google Meet was the platform used for synchronised teaching purposes. A short training session on how to use the platform was offered by a colleague to the learners and practitioner before the research. Other technological resources were also relied on to facilitate interaction or communication such as the Internet, Google Jamboard, Padlet, LINE, and interactive pens and digital graphics tablets.

The weekly 2-h distance teaching followed the original teaching syllabus and planned content without much alteration. The main difference was that the teaching and learning appeared in distance education mode, replacing the previous actual classroom instruction. This might be one of the quickest options or solutions when schools have to close at short notice, but education needs to continue. Each 2-h longdistance instruction was simultaneously recorded with the learners' permission for research use. After the first 2 hours of learning in their school dormitories where four students stayed in one room, the students had to return to the classroom to continue the ICLHE course for the third hour and were required to complete the online survey

\footnotetext{
${ }^{3}$ MOE of Taiwan announced that all schooling has to be moved online in a distance mode between 19 and 14 June 2021 due to its outbreak of local COVID-19 cases (MOE, 2021).
} 
directly after the distance learning. After the fourth week trial, the course resumed its normal face-to-face instruction.

The practitioner who taught the course and who was the researcher of the present study is an experienced English language (and ICLHE) teacher and researcher with over 15 years of experience at tertiary level. However, like many teaching faculty in Taiwan universities, he was less experienced in delivering distance learning courses before the pandemic. It is believed that by engaging as researchers to conduct action research in the classroom, teachers can develop their autonomy and renew their reflection on their teaching practices and roles in educational transformation [34]. ICLHE teachers as ICLHE researchers can be developers, evaluators, and facilitators of the ICLHE curriculum, helping them meet the needs of the students they teach [27] and broadening their concepts of both their professional practice and development [67].

\section{Instruments and Analysis}

We adopted a mixed-method methodological framework for the current study, integrating both quantitative and qualitative methods, which was suggested by Pérez-Cañado [76] to investigate CLIL issues. Firstly, we designed an online questionnaire survey (see Appendix), consisting of three dimensions to measure the students' feedback on the practitioner's performance, their learning effectiveness under synchronous distance ICLHE instruction, and the instructional platform. The survey included 32 close-ended and one open-ended question in two main sections: the first part (6 items) was about the informants' demographic information such as gender, language proficiency, content achievement in the midterm examination, and experiences of receiving distance education, while the second part (26 items) combined the established and perceived features or benefits of conducting distance and ICLHE education under three dimensions. For easy comprehension, the survey was originally designed and administered in Chinese but was then translated into English for writing the report. Before the formal distribution, the form was piloted, and reliability reached Cronbach's alpha .982 . The same survey was repeated four times and analysed with the help of SPSS 23.0. Besides the descriptive data, one-way ANOVA and multiple regression analysis were also run to determine any scale predictors and differences across the time span and variables. Instead of only reporting p-value, we also describe the operation of regression and effect size $(r)$ in the variants, as the effect size benchmark system is regarded as being more vital than the statistical significance level in inferential statistical procedures, and reporting effect size is becoming good practice, not only in applied linguistics empirical research but also in multilingualism studies to reveal the strength of the relationship between two variables (Larson-Hall, 2012; [100, 101]).

Secondly, we invited five students to join an in-depth focus group interview. The students were selected purposefully according to their gender, language proficiency, and content achievement. It was our hope to generate differentiated viewpoints about distance ICLHE instruction from the learners with diverse backgrounds. The interview was conducted in Chinese and lasted for approximately $1 \mathrm{~h}$. The questions mainly concerned their perceived gains and losses in the new ICLHE learning model. The data 
were transcribed into English for analysis using the grounded theory approach [33] to code, link, and generate similar ideas or concepts and were treated as complements to the quantitative results. We also relied on the four recorded 2-h streaming videos as a cross-reference to support or reject the findings in the previous stages. One of the researchers, also as the course practitioner, observed and reflected on his own practices to help him become an evaluator of judging his teaching effectiveness under an alternative instruction mode.

\section{Results and Discussion}

\section{Learners' Evaluation of the Three Dimensions in Distance Education}

The questionnaire is composed of three dimensions, namely students' evaluation of learning effectiveness in a distance ICLHE course with 15 items (LED), the dimension of judging the practitioner's teaching performance in the distance/online education model with eight items (TPD), and the assessment of the online delivery platform with three items (OPD). The participants' demographic information is shown in Table 1 and indicates that the language proficiency of most students is at intermediate (B2) level $(47.5 \%)$, and the scores of a majority of students' content achievement range between 71 and 80 . The majority of students are female $(75 \%)$, and $90 \%$ of the participants had previous distance education experience.

Table 2 reveals the overall descriptive results across the 4 weeks, on the dimensions of evaluating learning effectiveness (LED) ranging from 80.90 to 81.35 , and SD from 16.10 to 18.21 ; on the dimension of assessing the teacher's performance (TPD) ranging from 43.40 to 44.98 , with SD varying from 0.28 to 10.46 ; and on the dimension of judging the functions of online delivery platform (OPD), varying between 16.30 and 17.23 , and $\mathrm{SD}$ in the range of 3.33 to 3.80 . The means of the overall score fluctuate between 140.43 and 143.43 , while SD ranges from 28.52 to 31.98 .

Table 1 Demographic information of the participants (N=40)

\begin{tabular}{llll}
\hline Variable & Category & N & $\%$ \\
\hline Gender & Female & 30 & 75 \\
& Male & 10 & 25 \\
English language proficiency in TOEIC (equivalent to CEFR) & $>880(\mathrm{C} 2)$ & 2 & 5 \\
& $751-880(\mathrm{C} 1)$ & 13 & 32.5 \\
& $551-750(\mathrm{~B} 2)$ & 19 & 47.5 \\
Content achievement of the mid-term examination (test scores: 0-100) & $81-90$ & 6 & 15 \\
& $71-80$ & 7 & 17.5 \\
& $61-70$ & 20 & 50 \\
Experience of distance education & $\leq 60$ & 11 & 27.5 \\
& Yes & 2 & 5 \\
& No & 36 & 90 \\
\end{tabular}


Table 2 The descriptive statistics of the evaluation of the distance education model

\begin{tabular}{|c|c|c|c|c|c|c|c|c|}
\hline \multirow[t]{2}{*}{ Time } & \multicolumn{2}{|c|}{ The overall score } & \multicolumn{2}{|l|}{$\begin{array}{l}\text { LED, Learning } \\
\text { effectiveness }\end{array}$} & \multicolumn{2}{|l|}{$\begin{array}{l}\text { TPD, Teaching } \\
\text { performance }\end{array}$} & \multicolumn{2}{|l|}{$\begin{array}{l}\text { OPD, Delivery } \\
\text { platform }\end{array}$} \\
\hline & Mean $(\%)$ & $\mathrm{SD}$ & Mean $(\%)$ & $\mathrm{SD}$ & Mean $(\%)$ & $\mathrm{SD}$ & Mean $(\%)$ & $\mathrm{SD}$ \\
\hline Week 1 & $143.43(78.81)$ & 31.98 & $81.23(77.36)$ & 18.21 & $44.98(80.32)$ & 10.46 & $17.23(82.05)$ & 3.77 \\
\hline Week 2 & $141.80(77.91)$ & 28.79 & 81.35 (77.48) & 16.74 & $43.70(78.04)$ & 9.28 & $16.75(79.76)$ & 3.33 \\
\hline Week 3 & $140.43(77.16)$ & 28.52 & $80.73(76.89)$ & 16.10 & $43.40(77.50)$ & 9.54 & $16.30(77.62)$ & 3.41 \\
\hline Week 4 & $141.88(77.96)$ & 30.32 & $80.90(77.05)$ & 17.33 & $44.50(79.46)$ & 9.97 & $16.47(78.43)$ & 3.80 \\
\hline
\end{tabular}

Figure 1 shows the trajectory changes of the three individual dimensions and the overall evaluation. It can be seen that the learners showed the highest agreement in week 1 and the lowest in week 3. Although the averages slightly rebounded in week 4, in general their agreement gradually dropped across the time span. The initial trial may have been novel and motivating, but their interest could not persist until the end. It was found that week 3 comprised too much of the teacher's monologue, i.e. an apparent unequal speech distribution between the teacher and students, which deprived the students of chances for interaction, and easily led to their fatigue or distraction, and thus their lower acceptance. Compared to the other two dimensions, the learners evaluated their learning effectiveness the lowest, indicating that they were monitoring their learning relatively cautiously and critically, and were aware of their learning efficacy changes. This contradicts the Ministry of Education's intention to suspend extensive and longitudinal implementations of distance learning due to the worry that students are unaware of their learning efficacy. Furthermore, it is also interesting to note

\section{The trajectory changes of the overall and 3 dimensions evaluation}

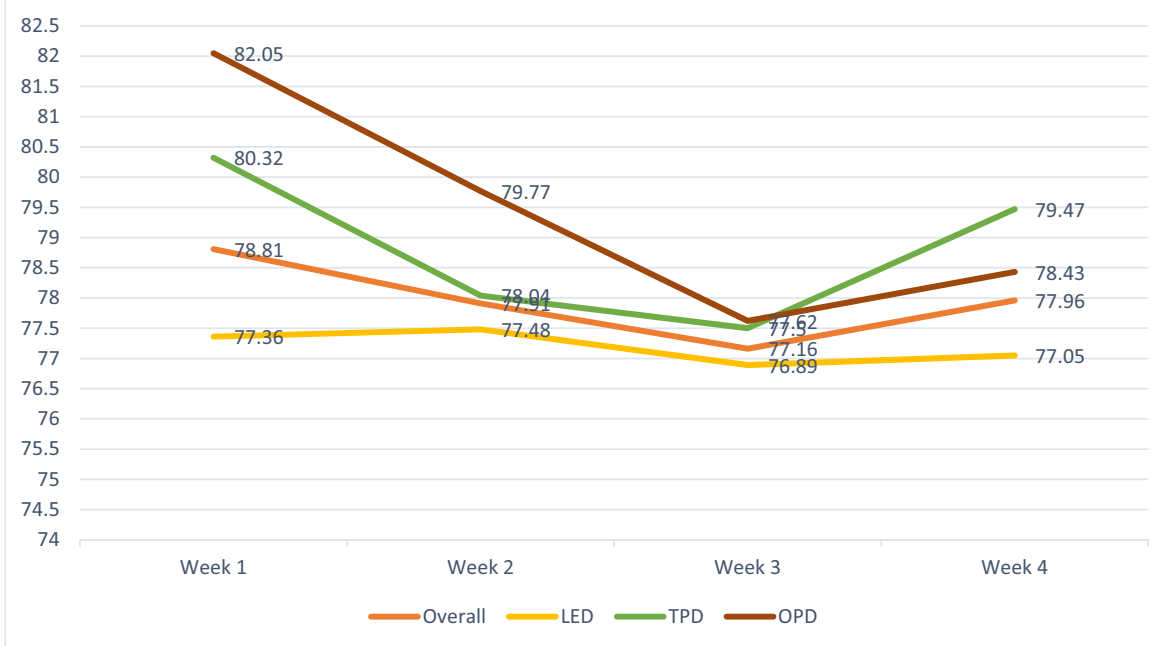

Fig. 1 The trajectory changes on the overall and 3 dimensions of evaluating distance education 
that the OPD follows the trajectory patterns of the other two dimensions, even when the platform and its functions remained identical. Thus, LED, TPD, and OPD were interwoven and cannot be separated when distance education is appraised. Yet, unfortunately our study cannot answer if the students' judgements of LED and TPD would change when using other instructional media.

Mauchly's tests were not significant, indicating that the assumption of sphericity was not violated. $\chi^{2}(5)=4.84, p=.44>.05$ for the overall evaluation, and $\chi 2(5)=5.22$,

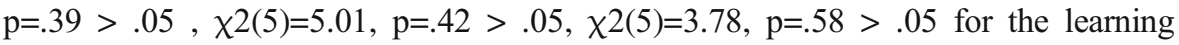
effectiveness of the distance ICLHE course, the dimension of the teacher's performance, and satisfaction with the instructional platform, respectively. As shown in Table 3, one-way repeated-measures ANOVA revealed that $F_{(3,117)}=.071, p=.976$ $>.05$ for the overall evaluation, and the corresponding effect size partial $\eta^{2}$ was .002 which fell below the small effect size benchmark (.01) (Cohen, 1988). The subdimension of LED was with the $\mathrm{F}_{(3,117)}=.012, \mathrm{p}=.998>.05$; the subdimension of TPD was with the $\mathrm{F}_{(3,117)}=.226, \mathrm{p}=.878>.05$; and the subdimension of OPD was with the $\mathrm{F}_{(3,117)}=.548, \mathrm{p}=.650>.05$. It could be found that the effect size partial $\eta^{2}$ of the OPD subdimension was .014 being the greatest and suggesting a small effect $(>.01)$, and the TPD subdimension was .006; they both belonged to the teacher's effect in the bins of .010 and .022 [35]; however, the partial $\eta^{2}$ of the subscale of LED was .000 which is much lower than the small effect size index. An examination of paired-samples T test was further conducted, and it was found that the effect sizes $(r)$ for OPD1 and OPD3, OPD1 and OPD4, and for TPD1 and TPD4 were .161, .109, and .123, respectively (see Table 4). This result suggested that the correlation strength of the two subdimensions on week 1 and week 3 , as well as of the subdimension OPD on week 1 and week 4, exceeded Cohen's 'small benchmark'.

However, when we compared the entry and exit values in the three dimensions, some minor differences were detected (see Fig. 2). For instance, the learners marked item 3 (distance learning is the only option in the pandemic) as the lowest acceptance in 3 weeks and item 1 (distance learning is novel and interesting) the lowest in 1 week, indicating that they were resistant to the ICLHE course delivered via distance learning mode. During the pandemic, distance or online education is not simply an assistance to learning but replaces real classroom learning, likely making the learners cautious and hesitant. In contrast, item 2 (M:5.12 vs. M:5.47) (synchronised distance learning

Table 3 Summary of the subject-within effect for one-way repeated measures

\begin{tabular}{|c|c|c|c|c|c|c|c|c|}
\hline Source & Sum of squar & & $\mathrm{df}$ & Mean square & $\mathrm{F}$ & Sig. & Effect size $\left(\eta^{2}\right)$ & $r$ \\
\hline \multirow[t]{2}{*}{ Overall } & Main effect & 180.42 & 3 & 60.14 & .071 & .976 & .002 & .045 \\
\hline & Residual & 99583.33 & 117 & 8851.14 & & & & \\
\hline \multirow[t]{2}{*}{ LED } & Main effect & 9.950 & 3 & 3.317 & .012 & .998 & .000 & .000 \\
\hline & Residual & 32472.55 & 117 & 277.54 & & & & \\
\hline \multirow[t]{2}{*}{ TPD } & Main effect & 62.719 & 3 & 20.906 & .226 & .878 & .006 & .078 \\
\hline & Residual & 10834.03 & 117 & 92.60 & & & & \\
\hline \multirow[t]{2}{*}{ OPD } & Main effect & 19.525 & 3 & 6.508 & .548 & .650 & .014 & .118 \\
\hline & Residual & 1388.48 & 117 & 11.87 & & & & \\
\hline
\end{tabular}


Table 4 Correlations of the OPD and TPD subdimensions

\begin{tabular}{llll}
\hline & OPD1-OPD3 & OPD1-OPD4 & TPD1-TPD3 \\
\hline Effect size $(r)$ & .161 & .109 & .123 \\
$p$ & .314 & .480 & .442 \\
\hline
\end{tabular}

enhances confidence in learning) received the highest positive increase, while item 24 (M:5.72 vs. M:5.58) (the practitioner keeps an enthusiastic teaching attitude) shows the highest negative increase after 4 weeks, indicating that the practitioner may have also gradually felt the ineffectiveness or fatigue of using online instruction, which affected his teaching performance and was sensed by the learners. How to keep both learners and practitioners continually motivated when using distance learning mode is a challenge for educational authorities, when requiring both parties to stay at 'a learning distance' without giving time for preparation.

\section{Predicators of Accepting the Distance Learning Model}

Since there is no 'one size fit all' CLIL pedagogy [102], it is assumed that distance education may not suit all students' learning styles either. Thus, to further understand whether the value of satisfaction with the distance learning model can be predicted based on gender, language proficiency, content achievement, and previous experiences of receiving distance education, multiple regression analysis was also performed. First, the average scores of the evaluations in the 4 weeks were computed, which represented the dependent variable. The results of the regression indicated that the model explained $13 \%$ of the variability of the dependent variable. The F-ratio, $F_{(9,30)}=.48, p=.88>.05$

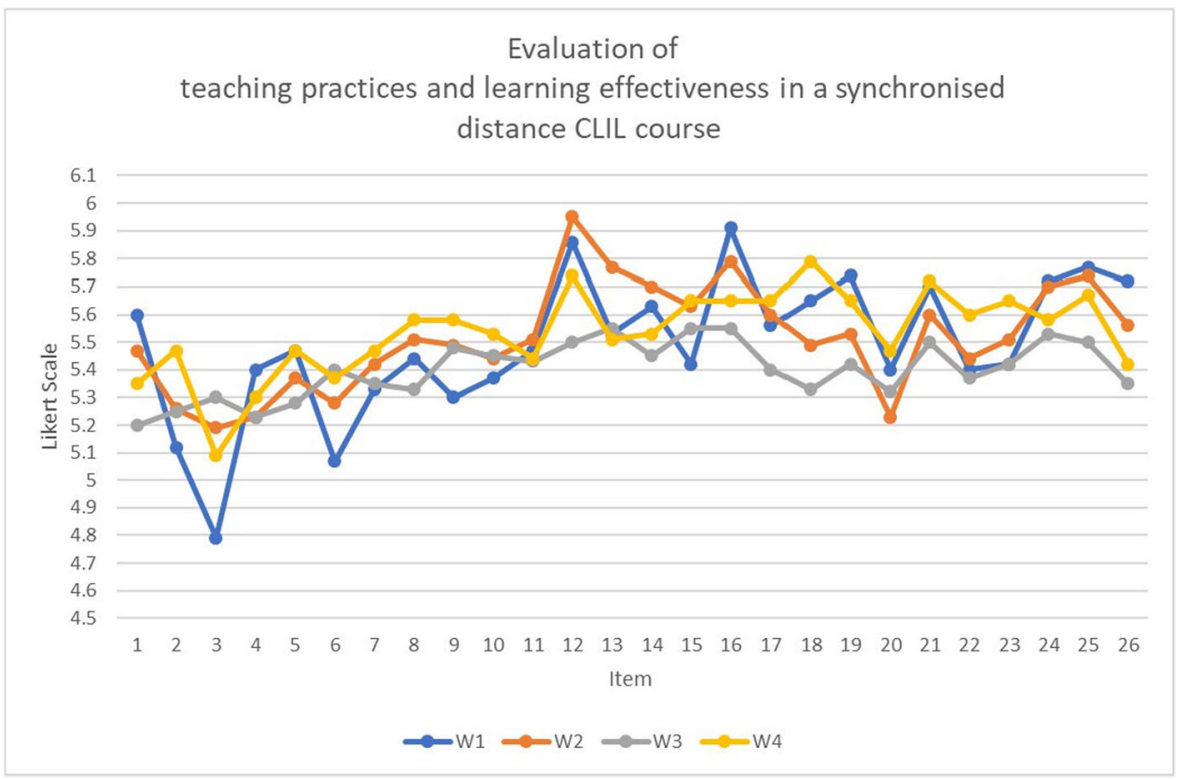

Fig. 2 Learners' evaluation of distance education on each item across the 4 weeks 
reveals that the independent variables do not statistically significantly predict the dependent variable based on the average scores of the evaluation for 4 weeks of ICLHE courses in the distance education model.

The final predictive model could be expressed after conducting multiple regressions as follows:

the average scores of the evaluations $=-.08 *$ gender $+.05 *$ experience $-.17 *$ toe 1

$$
+.16 * \text { toe } 3-.02 * \text { toe } 4-.06 * \text { toe } 5-.34 * \operatorname{mid} 2-.57 * \operatorname{mid} 3-.56 * \operatorname{mid} 4
$$

The values of the standardised coefficients (Beta) of the experience and English proficiency were .05 and .16 with only both independent variables positive which means that the students who had previous experience of distance education and whose English proficiency was level 3 (toe3) evaluated the teaching performance and learning effectiveness in the distance education model positively and were more satisfied with this approach. Besides, the students whose TOEIC scores ranged from 751 to 880 predicted the average scores of the evaluations increasing $16 \%$. It is understandable that those whose English proficiency is at advanced and lower levels were less satisfied with the ICLHE course delivered via distance education mode as there are noticeably fewer chances for elite students to use the target language due to the lack of group work or interaction, while low-level students cannot easily rely on peers' assistance with their language output in online learning environments. Learners not only suffer higher cognitive loading in processing both language and content at the same time [79], but also employ different language learning strategies in the ICLHE classroom [105]. It seems they will feel overloaded if the classroom becomes virtual since they need additional learning strategies to manage and evaluate their learning achievements [9]. However, it is surprising to know that the male students showed more positive attitudes than the females did, which contradicts most studies addressing gender differences in online learning (see [110]). It may be risky to conclude that the male students in this study were self-disciplined, self-motivated, or self-regulated online learners; they may in fact be shy and quiet and so feel more comfortable when less required to use the target language in public. Presumably, this discovery could only be relevant to the ICLHE approach when it is used in distance learning mode.

\section{Vigilant Attitude Towards Distance Education in the Interviews}

Judging from the interviewees' responses, it seems that the distance or online education model has more shortcomings than advantages. Their opinions can be categorised into the following themes.

The Virtual Classroom Is Irreversible During the Pandemic Conducting the distance or online teaching model is a spontaneous reaction to maintain education during school lockdown, and this will become normal if the pandemic continues. Some of the interviewees even believed that distance or online teaching would replace formal classroom instruction in the future. As one male student argued, 'The major benefit of this instructional model is its flexibility of learning time and location, empowering us to control our learning pace and manage our schedule'. In addition, a virtual classroom 
also helps eliminate the restrictions of a physical classroom. One female interviewee expressed the opinion that one strength of learning on a cyber platform is that it enables each student to see what the instructor would like to project on the screen and to make a screenshot of it for note-taking purposes. Moreover, it is relatively immediate and timesaving to hear students' oral responses or see their written productions in public. As one male student remarked, 'We can quickly share our spoken or written answers to the whole class when the responses are transmitted via the online platform'. This response indicates that online learning can facilitate 'one-way' information transmission; however, whether mutual interaction can occur to an equivalent degree is still questionable. Hence, the students suggested that a totally lecture-based content course can be delivered in this learning mode, but ICLHE courses may be unsuitable for this instructional manner.

The Actual Classroom Is Irreplaceable in the Future Nearly all the respondents held a dubious attitude towards the effectiveness of learning in the distance or online learning mode. The primary concerns are a lack of peer pressure, a loss of concentration, and little interaction and collaboration, which all occurred less than they would in a real classroom. Peer pressure can be vital to maintain concentration in class, and without it, students can be distracted easily. One male student noted that, 'My classmates can remind me of where we are in the teaching process and keep me concentrated as they as well as the teacher can easily see me face-to-face'. Another male student also commented that, 'Sitting and learning in front of the computer definitely disturbs me as I can use the Internet conveniently to browse other irrelevant web content'. Female interviewees expressed the complaint of less frequent interaction and collaboration with peers and teachers in distance learning. As one of them said, 'Unlike the classroom teaching where we can talk, interact, work and share with others very easily and commonly, distance learning grants us few chances to do that'. Another female student commented, 'Many communicative activities in a group or pair cannot be done due to the restrictions of the delivery platform. For hosting a meeting, the platform is okay, but for teaching and learning scenarios the functions are too basic to be helpful or effective'. Other dissatisfactions include the unstable quality of the Internet connection, malfunctioning audio-visual equipment [70], paying full tuition [36], and issues of privacy violation and identification theft, casting doubts on the value and inexorability of offering distance or online education.

The ICLHE Course Should be Re-designed Since the present ICLHE course aims to accommodate dual focuses, but language training is less likely due to the limitations of the delivery platform, ICLHE courses need to be re-blended under a distance learning mode. The interviewees expressed their interest in designing language scaffolding activities and assessments specifically for online learning purposes and suggested that the practitioner could adapt the teaching methods for online mode. As one respondent remarked, 'Ordinary paper-and-pencil tests are no longer appropriate in this situation and probably teachers have to design tests which have no fixed answers to maintain fairness'. Another student said, 'Teachers need to provide us with more opportunities to practise our English ability by picking better software or platforms, and varying their voice pitch to attract us, as unfortunately it always sounds very flat via digital streaming'. Apparently, both ICLHE courses and teachers require substantial 
modifications to fit the context of distance teaching. Apparently, ICLHE teachers need additional pedagogical skills and learners and, in particular, have to be instructed in new learning strategies for distance learning education.

\section{Conclusion and Implications}

This study scrutinised the effectiveness of ICLHE teaching and learning under a distance education model when schools are in lockdown during the pandemic. Thus, we simulated 4 weeks of ICLHE lessons delivered in a synchronous manner to understand how the university learners would judge the practitioner's performance and their learning experiences compared to the ordinary face-to-face classroom instruction. The quantitative results demonstrate that, in general, the learners held a moderately satisfactory attitude towards the effectiveness of the distance ICLHE instruction, but the degree of agreement decreased gradually across the time span. Besides, it could be predicted that the distance ICLHE learning model might be welcomed by male learners and those whose English levels are at an intermediate level (rather than either basic or high levels) with their content achievement ranging from intermediate to high (not low). However, the qualitative data show that the ICLHE learners held a much more reserved and hesitant attitude towards the distance education model, as they were concerned about communication, interaction, peer pressure, and learner autonomy. In addition, how the practitioner delivered the content and what activities both the teacher and learners engaged in each week may affect the ICLHE learners' judgement.

The study has the following pedagogical implications. First, before distance or online teaching is highly recommended by schools and becomes the only alternative to maintain education during the pandemic, one essential question is whether or not teachers are ready for it, that is, are they equipped with sufficient informationtechnology (IT) knowledge and literacy to fully operate the platforms or media? More assistance may have to be offered to teachers to lessen their uncertainty and anxiety in unfamiliar instruction environments; pre-trained teaching assistants (TA) or research assistants (RA) might be helpful [107]. Secondly, in a learner-centred distance education model, teachers are also facing a transformation of their roles and identities, in particular at tertiary level. University teachers might often be lecturers in real classrooms, but they have to switch their roles to not only become facilitators promoting autonomous and self-directed learning and empowering students to learn at their own pace, but also intermediaries between students and the available technological resources. CLIL teachers have to help learners realise how the various materials and IT resources can suit different learning needs and overcome the limitations of time and distance [5].

Finally, conducting distance instruction requires many behavioural and conceptual adaptations on the part of ICLHE practitioners. These changes may include considering what assessments can be administered and how; creating a schedule for meaningful and active involvement; still being human to listen and talk; showing empathy for what learners see in front of the screen; organising course content in a clear, methodological, and intuitive manner; and adding virtual appeals to motivate and engage learners. Besides, ICLHE teachers are expected to clearly explain their 
expectation of students' performance in the dual focuses, re-scaffold learning activities used in a less interactive situation, model the examples to help learners capture the content confidently, and be willing to improve continuously for professional development [19]. In other words, to make learning enjoyable and interesting, the ICLHE distance education model requires a complete re-design of teaching, making it distinct from the ordinary classroom practices that teachers and learners are used to. Also, it requires practitioners to show their commitment to improving their teaching and to making it fresh and better by using both internal and external teaching-supported resources well, as distance/online classrooms still differ greatly from physical classrooms [19].

Since the present research may be one of the few studies to investigate ICLHE instruction conducted via the synchronous distance education model in response to school lockdown due to the pandemic, many future explorations can be carried out to complement it. First, the number of participants was limited, and they were relatively homogeneous (e.g. all English majors in one department). More participants from other academic disciplines can be invited to achieve higher representativeness. The experimental time can be extended to achieve higher validity of evaluating effectiveness and to eliminate the possible variable of novelty, affecting the motivation of learning in the distance education model. Moreover, learners' achievement test scores in both language and content can be used as hard and objective evidence to assess the learning effectiveness [63]. Third, owing to the fact that distance education or online learning is still not fully recognised by law in Taiwan, and thus a tailor-made simultaneous and synchronised model was adopted in the present study, it is suggested that future studies design an asynchronous model where learners can take an ICLHE course at their own pace in their own place, which may lead to different findings from those of the present study. Besides, an analysis of virtual classroom interaction can be another direction for providing a clear picture of online ICHLE courses.

\section{Appendix. Questionnaire of evaluating teaching practices and learning effectiveness in a synchronised distance ICLHE course}

\section{Demographic information}

1. Gender, 2. Study year, 3. English proficiency, 4. Experiences of distance learning, 5. Platform of distance learning, 6. Mid-term content text score, 7. Mid-term English score

\section{Question items (Likert scale ranging from 1: lowest agreement to 7: highest agreement)}

1. Synchronised distance learning (SDL) is interesting and novel.

2. SDL enhances my confidence in learning.

3. SDL is the only option in a school lockdown.

4. SDL is suitable for running the current course (Introduction to Hospitality in CLIL).

5. I can cope with the course well in SDL mode. 
6. I still have opportunities to use English actively in SDL mode.

7. I remain interactive with the instructor and classmates in SDL mode.

8. I still receive immediate assistance in SDL mode like in a real classroom.

9. I can learn something from my classmates even in SDL mode.

10. I still exhibit my critical thinking skills in SDL mode.

11. I still demonstrate cultural sensitivity in SDL mode.

12. I show equal respect to others during online discussion in SDL mode.

13. I still keep a self-disciplined attitude in SDL mode.

14. I can clearly comprehend the content instructed by the practitioner in SDL mode.

15. I change my learning styles to fit SDL mode.

16. The platform of delivering SDL is user-friendly.

17. The functions of the platform of delivering SDL are satisfactory.

18. The practitioner takes good control of the teaching pace in SDL mode.

19. The practitioner gives timely feedback to learners' questions in SDL mode.

20. The practitioner attends to my learning performance (or response) in SDL mode in a timely manner.

21. The practitioner clearly instructs the subject content in SDL mode.

22. The practitioner offers feedback on my language use in SDL mode.

23. The practitioner allows chances for peer interaction and communication.

24. The practitioner still keeps an enthusiastic teaching attitude in SDL mode.

25. The practitioner still addresses content and language equally in SDL mode.

26. In general, I am satisfied with the CLIL course in SDL mode.

27. [Please provide any of your comments on the course delivered in SDL mode below.]

Funding The research was sponsored by the Ministry of Sciences and Technology, Taiwan (MOST 1082410-H-328-002).

\section{Declarations}

Conflict of interest The authors declare no competing interests.

\section{References}

1. Almanthari, A., Maulina, S., \& Bruce, S. (2020). Secondary school mathematics teachers' views on Elearning implementation barriers during the COVID-19 pandemic: The case of Indonesia. Eurasia Journal of Mathematics, Science and Technology Education, 16(7), 1-9.

2. Badertscher, H., \& Bieri, T. (2009). Wissenserwerb im content and language integrated learning [Acquisition of knowledge in Content and Language Integrated Learning].

3. Ball, P. (2009). Does CLIL work? In D. A. Hill \& A. Pulverness (Eds.), The best of both worlds? International Perspectives on CLIL (pp. 32-43). Norwich Institute for Language Education.

4. Banegas, D. L. (2012). Integrating content and language in English language teaching in secondary education: Models, benefits, and challenges. Studies in Second Language Learning and Teaching, 2(1), 111-136.

5. Beaudoin, M. (1990). The instructor's changing role in distance education. American Journal of Distance Education, 4(2), 21-29.

6. Brown, B. W., \& Liedholm, C. E. (2002). Can web courses replace the classroom in principles of microeconomics? American Economic Review, 92(2), 444- 448. 
7. Capone, R., Del Sorbo, M. R., \& Fiore, O. (2017). A flipped experience in physics education using CLIL methodology. EURASIA Journal of Mathematics, Science and Technology Education, 10(13), 6579-6582.

8. Carloni, G. (2012). Online CLIL scaffolding at university level: Building vocabulary across disciplines through online learning. In CALL: Using, Learning, Knowing. Proceedings of the EUROCALL 2012 Conference. Gothenburg, Sweden (pp. 37-42).

9. Chang, S. L., \& Ley, K. (2006). A learning strategy to compensate for cognitive overload in online learning: Learner use of printed online materials. Journal of Interactive Online Learning, 5(1), 104-117.

10. Cohen, J. (1988). Statistical power analysis for the behavioural sciences (2nd ed.). Lawrence Erlbaum

11. Coyle, D. (2004). Supporting students in CLIL contexts: Planning for effective classroom. Learning through a Foreign Language (pp. 40-54). Lancaster.

12. Coyle, D. (2006). Developing CLIL: Towards a theory of practice. In Monograph 6. APAC. Barcelona.

13. Coyle, D. (2011). Post-method pedagogies: Using a second or other language as a learning tool in CLIL settings. In Y. R. Ruiz de Zarobe, J. M. Sierra, \& F. G. Puerto (Eds.), Content and Foreign Language Integrated Learning: Contributions to Multilingualism in European Contexts (pp. 49-73). Peter Lang.

14. Coyle, D. (2013). Listening to learners: An investigation into 'successful learning' across CLIL contexts. International Journal of Bilingual Education and Bilingualism, 16(3), 244-266.

15. Coyle, D., Hood, P., \& Marsh, D. (2010). CLIL: Content and Language Integrated Learning. Cambridge University. Press.

16. Dalton-Puffer, C. (2007). Discourse in Content and Language Integrated (CLIL) classrooms. John Benjamins.

17. Dalton-Puffer, C. (2008). Outcomes and processes in Content and Language Integrated Learning (CLIL): Current research from Europe. In W. Delanoy \& L. Volkmann (Eds.), Future Perspectives for English Language Teaching (pp. 139-157). Carl Winter.

18. Dalton-Puffer, C. (2011). Content and Language Integrated Learning: From practice to principles? Annual Review of Applied Linguistics, 31, 182-204.

19. Darby, F. (2020). How to be a better on-line teacher. In Moving on-line now: How to keep teaching during coronavirus? (pp. 12-23). The Chronicle of Higher Education.

20. De Graaff, R., Koopman, G. J., \& Westhoff, G. (2007). Identifying effective L2 pedagogy in content and language integrated learning (CLIL). Vienna English Working Papers, 16(3), 12-19.

21. De Santo, M., \& De Meo, A. (2016). E-training for the CLIL teacher: e-tutoring and cooperation in a Moodle-based community of learning. Journal of e-Learning and Knowledge Society, 12(3), 41-49.

22. De Waard, I., \& Demeulenaere, K. (2017). The MOOC-CLIL project: using MOOCs to increase language, and social and online learning skills for 5 th grade K-12 students. In K. Qian \& S. Bax (Eds.), Beyond the Language Classroom: Researching MOOCs and other Innovations (pp. 29-42). Research Publishing.

23. Denman, J., Tanner, R., \& Graaff, R. (2013). CLIL in junior vocational secondary education: Challenges and opportunities for teaching and learning. International Journal of Bilingual Education and Bilingualism, 16(3), 285-300.

24. Fernández, R., \& Halbach, A. (2011). Analysing the situation of teachers in the Madrid bilingual project after four years of implementation. In Y. R. de Zarobe (Ed.), Content and foreign language integrated learning: Contributions to multilingualism in European contexts (pp. 241-270). Peter Lang.

25. Finardi, K. R. (2015). Current trends in ELT and affordances of the inverted CLIL approach. Studies in English Language Teaching, 3(4), 326-338.

26. Florini, B. M. (1990). Communications technology in adult education. In M. W. Galbraith (Ed.), Adult learning methods: A guide for effective instruction. Krieger.

27. Fueyo, V., \& Koorland, M. A. (1997). Teacher as researcher: A synonym for professionalism. Journal of Teacher Education, 48(5), 336-344.

28. Fürstenberg, U., \& Kletzenbauer, P. (2012). CLIL: From online sources to learning resources. In International Conference ICT in Language Learning. Retrieved on 16, July 2020 from https:// conference.pixel-online.net/conferences/ICT4LL2012/common/download/Paper_pdf/149-CLI02-FPKletzenbauer-ICT2012.pdf

29. Garcia-Esteban, S., Villarreal, I., \& Bueno-Alastuey, M. C. (2019). The effect of telecollaboration in the development of the learning to learn competence in CLIL teacher training. Interactive Learning Environments, 1-14.

30. Garrison, D. R. (2003). Cognitive presence for effective asynchronous online learning: The role of reflective inquiry, self-direction and metacognition. Elements of Quality Online Education: Practice and Direction, 4(1), 47-58. 
31. Garrison, D. R., \& Shale, D. (1987). Mapping the boundaries of distance education: Problems in defining the field. American Journal of Distance Education, 1(1), 7-13.

32. Gierlinger, E. M., \& Wagner, T. A. (2016). The more the merrier-revisiting CLIL-based vocabulary growth in secondary education. Latin American Journal of Content \& Language Integrated Learning, 9(1), 37-63.

33. Glaser, B. G., \& Strauss, A. L. (2017). Discovery of grounded theory: Strategies for qualitative research. Routledge.

34. Hammersley, M. (1993). On the teacher as researcher. Educational Action Research, 1(3), 425-445.

35. Hattie, J. (2009). Visible learning: A synthesis of over 800 meta-analyses relating to achievement. Rutledge.

36. Hess, A. (2020). More than $93 \%$ of U.S. college students say tuition should be lowered if classes are online. CNBC (27 July, 2020). Retrieved on 1 August, 2020 from https://www.cnbc.com/2020/07/27/ 93percent-of-college-students-say-tuition-should-be-cut-for-online-classes.html

37. Hillyard, S. (2011). First steps in CLIL: Training the teachers. Latin American Journal of Content \& Language Integrated Learning, 4(2), 1-12.

38. HU (Harvard Unviersity). (2020). Decision for 2020-21 academic year. Retrieved on 24 July, 2020. from https://www.fas.harvard.edu/fas-decision-2020-2021-academic-year

39. Hüttner, J., Dalton-Puffer, C., \& Smit, U. (2013). The power of beliefs: Lay theories and their influence on the implementation of CLIL programmes. International Journal of Bilingual Education and Bilingualism, 16(3), 267-284.

40. Isssroff, K., \& Scanlon, E. (2002). Using technology in higher education: An activity theory perspective. Journal of Computer Assisted Learning, 18(1), 77-83.

41. James, W. B., \& Gardner, D. L. (1995). Learning styles: Implications for distance learning. New Directions for Adult and Continuing Education, 67, 19-31.

42. Kao, Y. T. (2020). Understanding and addressing the challenges of teaching an online CLIL course: A teacher education study. International Journal of Bilingual Education and Bilingualism, 1-20.

43. Kong, M., \& Wei, R. (2019). EFL learners' attitudes toward English-medium instruction in China: The influence of sociobiographical variables. Linguistics and Education, 52, 44-51.

44. Lancaster, N. K. (2016). Stakeholder perspectives on CLIL in a monolingual context. English Language Teaching, 9(2), 148-177.

45. Lara Herrera, R. (2015). Mexican secondary school students' perception of learning the history of Mexico in English. Profile Issues in Teachers Professional Development, 17(1), 105-120.

46. Larson-Hall, J. (2012). How to run statistical analyses. In A. Mackey \& S. M. Gass (Eds.), Research methods in second language acquisition: A practical guide (pp. 245-274). Chichester, UK: WileyBlackwell.

47. Lasagabaster, D. (2011). English achievement and student motivation in CLIL and EFL settings. Innovation in Language Learning and Teaching, 5(1), 3-18.

48. Liaw, S. S. (2008). Investigating students' perceived satisfaction, behavioural intention, and effectiveness of e-learning: A case study of the Blackboard system. Computers \& Education, 51(2), 864-873.

49. Liberali, F. C., \& Megale, A. (2016). Elite bilingual education in Brazil: an applied linguist's perspective. Colombian Applied Linguistics Journal, 18(2), 95-108.

50. Lin, A. M. (2016). Language across the curriculum \& CLIL in English as an additional language (EAL) contexts: Theory and practice. Springer.

51. Llinares, A. (2015). Integration in CLIL: A proposal to inform research and successful pedagogy. Language, Culture and Curriculum, 28(1), 58-73.

52. Lo, Y. Y. (2014). L2 learning opportunities in different academic subjects in content-based instruction: Evidence in favour of 'conventional wisdom'. Language and Education, 28(1), 141-160.

53. Lockley, T. (2015). Promoting international posture through history as content and language integrated learning (CLIL) in the Japanese context. Studies in Second Language Learning and Teaching, 5(1), 87108.

54. Lorenzo, F., Casal, S., \& Moore, P. (2010). The effects of content and language integrated learning in European education: Key findings from the Andalusian bilingual sections evaluation project. Applied Linguistics, 31(3), 418-442.

55. Marenzi, I., \& Zerr, S. (2012). Multiliteracies and active learning in CLIL - the development of LearnWeb2. 0. IEEE Transactions on Learning Technologies, 5(4), 336-348.

56. Marenzi, I., Kupetz, R., Nejdl, W., \& Zerr, S. (2010). Supporting active learning in CLIL through collaborative search. In Luo et al. (Eds.), International Conference on Web-Based Learning (pp. 200209). Springer. 
57. Marsh, D. (2002). Summary of major recommendations. In D. Marsh (Ed.), CLIL/EMILE-The European dimension: Actions, trends and foresight potential (pp. 9-13). University of Jyväskylä.

58. Mayo, M. D. P. G., \& Ibarrola, A. L. (2015). Do children negotiate for meaning in task-based interaction? Evidence from CLIL and EFL settings. System, 54, 40-54.

59. MIT (Massachusetts Institute Technology). (2020). MIT announces plans for fall 2020 semester. Retrieved on 24 July, 2020 from https://www.fas.harvard.edu/fas-decision-2020-2021-academic-year

60. MOE (Ministry of Education, Taiwan). (2021). On-line teaching extended due to the pandemic. Retrieved on 31 May, 2021 from https://www.edu.tw/News_Content.aspx? $\mathrm{n}=$ 9E7AC85F1954DDA8\&s=BD091C4ED7DC82F9

61. Moore, M. G., \& Kearsley, G. (2011). Distance education: A systems view of online learning. Cengage Learning.

62. Moore, J. L., Dickson-Deane, C., \& Galyen, K. (2011). e-Learning, online learning, and distance learning environments: Are they the same? The Internet and Higher Education, 14(2), 129-135.

63. Motiwalla, L., \& Tello, S. (2000). Distance learning on the internet: An exploratory study. The Internet and Higher Education, 2(4), 253-264.

64. Ni, A. Y. (2013). Comparing the effectiveness of classroom and online learning: Teaching research methods. Journal of Public Affairs Education, 19(2), 199-215.

65. Nikula, T. (2010). Effects of CLIL on a teacher's classroom language use. In C. Dalton-Puffer, T. Nikula, \& S. Ute (Eds.), Language use and language learning in CLIL classrooms (pp. 105-124). John Benjamins.

66. Nikula, T., Dalton-Puffer, C., \& García, A. L. (2013). CLIL classroom discourse: Research from Europe. Journal of Immersion and Content-Based Language Education, 1(1), 70-100.

67. Nunan, D. (1990). The teacher as researcher. In C. Brumfit \& R. Mitchell (Eds.), Research in the language classroom (pp. 16-32). British Council.

68. O'Dowd, R. (2018). Innovations and challenges in using online communication technologies in CLIL. Theory Into Practice, 57(3), 232-240.

69. Oxbrow, G. (2018). Students' perspectives on CLIL programme development: A quantitative analysis. Porta Linguarum, 29, 137-158.

70. Park, Y. J., \& Bonk, C. J. (2007). Synchronous learning experiences: Distance and residential learners' perspectives in a blended graduate course. Journal of Interactive Online Learning, 6(3), 245-264.

71. Parsons, M., \& Caldwell, M. (2016). Student attitudes to CLIL lessons utilising a problem-based approach to English language education at University in Japan. Journal of Hannan University the Hannan Ronshu, 51(2), 31-47.

72. Pellegrino, E., De Santo, M., \& Vitale, G. (2013). Integrating learning technologies and autonomy: A CLIL course in Linguistics. Procedia-Social and Behavioural Sciences, 106, 1514-1522.

73. Pérez Cañado, M. L. (2018). Innovations and challenges in CLIL teacher training. Theory Into Practice, 57(3), 1-10.

74. Pérez Cañado, M. L. (2018a). CLIL and pedagogical innovation: Fact or fiction? International Journal of Applied Linguistics, 28(3), 369-390.

75. Pérez Cañado, M. L. (2018b). Innovations and challenges in CLIL teacher training. Theory Into Practice, 57(3), 1-10.

76. Pérez-Cañado, M. L. (2012). CLIL research in Europe: Past, present, and future. International Journal of Bilingual Education and Bilingualism, 15(3), 315-341.

77. Piccoli, G., Ahmad, R., \& Ives, B. (2001). Web-based virtual learning environments: A research framework and a preliminary assessment of effectiveness in basic IT skills training. MIS Quarterly, 401-426.

78. Porto, M. (2018). Intercultural citizenship education in the language classroom. In I. Davies, L. Ho, D. Kiwan, C. Peck, A. Peterson, E. Sant, \& Y. Waghid (Eds.), The Palgrave Handbook of Global Citizenship and Education (pp. 489-506). Palgrave Macmillan.

79. Reitbauer, M., Fürstenberg, U., Kletzenbauer, P., \& Marko, K. (2018). Towards a cognitive-linguistic turn in CLIL: Unfolding integration. Latin American Journal of Content and Language Integrated Learning, 11(1), 87-107.

80. Richards, M., \& DeBonis, K. (2020). Psychiatric training during a global pandemic: How COVID-19 has affected clinical care, teaching, and trainee well-being. Psychiatric Services, 1-3 (PS in Advance)

81. Roiha, A., \& Sommier, M. (2018). Viewing CLIL through the eyes of former pupils: insights into foreign language and intercultural attitudes. Language and Intercultural Communication, 18(6), 631647.

82. Rose, S. (2020). Medical student education in the time of COVID-19. Journal of the American Medical Association, 323(21), 2131-2132. 
83. Ruiz de Zarobe, Y. (2008). CLIL and foreign language learning: A longitudinal study in the Basque country. International CLIL Research Journal, 1(1), 60-73.

84. Ruiz de Zarobe, Y. (2013). CLIL implementation: From policy-makers to individual initiative. International Journal of Bilingual. Education and Bilingualism, 16(3), 231-243.

85. Ruiz de Zarobe, Y., \& Lasagabaster, D. (2010). CLIL in a bilingual community: The Basque autonomous community. In D. Lasagabaster \& Y. Ruiz de Zarobe (Eds.), CLIL in Spain: Implementation, Results and Teacher Training (pp. 12-29). Cambridge Scholars.

86. Schmidt-Unterberger, B. (2018). The English-medium paradigm: A conceptualisation of Englishmedium teaching in higher education. International Journal of Bilingual Education and Bilingualism, 21(5), 527-539.

87. Seikkula-Leino, J. (2007). CLIL learning: Achievement levels and affective factors. Language and Education, 21(4), 328-341.

88. Sintema, E. J. (2020). Effect of COVID-19 on the performance of grade 12 students: Implications for STEM education. Eurasia Journal of Mathematics, Science and Technology Education, 16(7), 1-6.

89. Swan, K. (2003). Learning effectiveness online: What the research tells us. Elements of Quality Online Education, Practice and Direction, 4(1), 13-47.

90. Tafazoli, D., \& Golshan, N. (2014). Review of computer-assisted language learning: History, merits \& barriers. International Journal of Language and Linguistics, 2(5-1), 32-38.

91. Titova, S. (2017). The use of MOOC as a means of creating a collaborative learning environment in a blended CLIL course. In K. Borthwick, L. Bradley, \& S. Thouësny (Eds.), CALL in a climate of change: Adapting to turbulent global conditions-short papers from EUROCALL (pp. 306-311). Research Publishing Net.

92. UC (University of Cambridge). (2020). Update from the Vice-Chancellor. Retrieved on 24 July, 2020 from https://www.cam.ac.uk/coronavirus/news/update-from-the-vice-chancellor-22

93. UO (University of Oxford). (2020). Teaching remotely. Retrieved on 24 July, 2020 from https://www. ctl.ox.ac.uk/teaching-remotely

94. Varea, V., \& González-Calvo, G. (2020). Touchless classes and absent bodies: Teaching physical education in times of Covid-19. Sport, Education and Society, 1-15.

95. Verduin, J. R., \& Clark, T. A. (1991). Distance education: The foundations of effective practice. JosseyBass Inc Publication.

96. Walenta, M. (2018). Balancing linguistic and extra-linguistic gains in CLIL: a case for content-based structured input. International Journal of Bilingual Education and Bilingualism, 21(5), 578-590.

97. Wannagat, U. (2007). Learning through L2: Content and Language Integrated Learning (CLIL) and English as medium of instruction (EMI). International Journal of Bilingual Education and Bilingualism, 10(5), 663-682.

98. Wei, R. (2013). Chinese-English bilingual education in China: Model, momentum, and driving forces. Asian EFL Journal, 15(4), 184-200.

99. Wei, R., \& Feng, J. (2015). Implementing CLIL for young learners in an EFL context beyond Europe. English Today, 31(1), 55-60.

100. Wei, R., \& Hu, Y. (2019). Exploring the relationship between multilingualism and tolerance of ambiguity: A survey study from an EFL context. Bilingualism: Language and Cognition, 22(5), 1209-1219.

101. Wei, R., Hu, Y., \& Xiong, J. (2019). Effect size reporting practices in applied linguistics. research: A study of one major journal. SAGE Open, 9(2), 1-11. https://doi.org/10.1177/2158244019850035.

102. Wewer, T. (2017). An observation tool for comprehensive pedagogy in Content and Language Integrated Learning (CLIL): Examples from primary education. Colombian Applied Linguistics Journal, 19(2), 277-292.

103. Williams, P. W. (2009). Assessing mobile learning effectiveness and acceptance. Unpublished doctoral dissertation. Washington DC.: The George Washington University.

104. Wu, S. T. (2013). A study of the effect of satisfaction of the synchronous and asynchronous instructional design on learning outcome- with an example of Tamkang University, Unpublished master thesis. Taipei: Tamkang University.

105. Yang, W. H. (2017). From similarity to diversity: The changing use of language learning strategies in content and language integrated learning at the tertiary level in Taiwan. English Teaching \& Learning, 41(1), 1-32.

106. Yang, W. H. (2019). Developing tertiary level CLIL learners' intercultural awareness with a selfproduced coursebook integrating content and language. Journal of Teaching English for Specific and Academic Purposes, 7(3), 329-347. 
107. Yang, C. Y. (2020). The seven shadows of planning distance education for universities. Retrieved on 21 Jsuly, 2020 from https://medium.com/@yangchengyu/\%E8\%A7\%A3\%E6\%9E\%90-\%E5\%A4\%A7\% E5\%AD\%B8\%Е9\%9B\%A3\%E4\%BB\%A5-\%E8\%B6\%85\%Е5\%89\%8D\%E9\%83\%A8\%E7\%BD\% B2-\%E9\%81\%A0\%E8\%B7\%9D\%E6\%95\%99\%E5\%AD\%B8\%E7\%9A\%84\%E4\%B8\%83\%Е9\% $81 \% 93 \% \mathrm{E} 9 \% 99 \% \mathrm{~B} 0 \% \mathrm{E} 5 \% \mathrm{BD} \% \mathrm{~B} 1-1 \mathrm{fac} 83375 \mathrm{~d} 8 \mathrm{~b}$

108. Yang, W. H., \& Gosling, M. (2013). National appraisal and stakeholder perceptions of a tertiary CLIL programme in Taiwan. International CLIL Research Journal, 2(1), 67-81.

109. Yang, W. H., \& Gosling, M. (2014). What makes a Taiwan CLIL programme highly recommended or not recommended? International Journal of Bilingual Education and Bilingualism, 17(4), 394-409.

110. Yukselturk, E., \& Bulut, S. (2009). Gender differences in self-regulated online learning environment. Journal of Educational Technology \& Society, 12(3), 12-22.

\section{Affiliations}

\section{Wen-hsien Yang ${ }^{1} \cdot$ Li-zu Yang $^{2}$}

\section{Wen-hsien Yang}

yangwenhsien@mail.nkuht.edu.tw

Li-zu Yang

lizuyang@gmail.com

1 Department of Applied English, National Kaohsiung University of Hospitality and Tourism, 1, Hsung-ho Rd. Hsiao-kang Dist, 812 Kaohsiung, Taiwan

2 National Kaohsiung University of Hospitality and Tourism, 1, Hsung-ho Rd. Hsiao-kang Dist, 812, Kaohsiung, Taiwan 